\title{
Influence of Central Pacific Oceanographic Conditions on the Potential Vertical Habitat of Four Tropical Tuna Species
}

\author{
AL Deary \\ Virginia Institute of Marine Science \\ S Moret-Ferguson \\ M Engels \\ E Zettler \\ G Jaroslow
}

Follow this and additional works at: https://scholarworks.wm.edu/vimsarticles

Part of the Aquaculture and Fisheries Commons

\section{Recommended Citation}

Deary, AL; Moret-Ferguson, S; Engels, M; Zettler, E; and Jaroslow, G, "Influence of Central Pacific Oceanographic Conditions on the Potential Vertical Habitat of Four Tropical Tuna Species" (2015). VIMS Articles. 828.

https://scholarworks.wm.edu/vimsarticles/828 


\title{
Influence of Central Pacific Oceanographic Conditions on the Potential Vertical Habitat of Four Tropical Tuna Species ${ }^{1}$
}

\author{
Alison L. Deary, ${ }^{2,6}$ Skye Moret-Ferguson, ${ }^{3}$ Mary Engels, ${ }^{3}$ \\ Erik Zettler, ${ }^{3}$ Gary Jaroslow, ${ }^{4}$ and Gorka Sancho ${ }^{5}$
}

\begin{abstract}
Climate change has resulted in the geographic and vertical expansion of oxygen minimum zones but their impact on the vertical distribution of commercially important species, such as tunas, is not well understood. Although La Niña events are characterized by increased upwelling along the equator, the increased primary productivity and bacterial proliferation drive the expansion of oxygen minimum zones. Vertical habitat of four tropical tuna species were characterized using direct observations of the oceanographic conditions of the Central Pacific Ocean during the 2008 La Niña event and existing primary literature on temperature and dissolved oxygen physiological tolerances for these tunas. Concentrations of potential prey were estimated using Acoustic Doppler Current Profiler raw backscatter and surface zooplankton tows. Based on the oceanographic conditions observed from February to June, low dissolved oxygen levels, more so than low temperatures, were inferred to restrict the predicted vertical habitat of four commercially important tuna species (bigeye, yellowfin, skipjack, and albacore). During peak La Niña conditions, temperature and dissolved oxygen tolerance limits of all four tuna species were reached at approximately $200 \mathrm{~m}$. Zooplankton and myctophid fish densities peaked in the upper $200 \mathrm{~m}$ between $0^{\circ} \mathrm{N}$ and $5^{\circ} \mathrm{N}$, which corresponded to a region with a shallow thermocline $(150 \mathrm{~m})$. Our findings suggest the possibility that competition and susceptibility to surface fishing gears may be increased for tropical tunas during a strong La Niña event due to vertical habitat restrictions.
\end{abstract}

Oxygen minimum zones (OMZs) are persistent, mid-water layers with oxygen concentrations $<23.3 \mu \mathrm{mol} / \mathrm{kg}$ (Levin 2003). In the tropical Equatorial Pacific Ocean, OMZs

\footnotetext{
${ }^{1}$ This work was funded by a National Science Foundation GK-12 PERFECT grant and a National Oceanic and Atmospheric Administration Hollings Scholarship. Manuscript accepted 15 February 2015.

${ }^{2}$ Virginia Institute of Marine Science, 1208 Greate Road, Gloucester Point, Virginia 23062.

${ }^{3}$ Sea Education Association, PO Box 6, Woods Hole, Massachusetts 02543.

${ }^{4}$ Massachusetts Maritime Academy, 101 Academy Drive, Buzzards Bay, Massachusetts 02532.

${ }^{5}$ College of Charleston, 205 Fort Johnson Road, Charleston, South Carolina 29412.

${ }^{6}$ Corresponding author (e-mail: aldeary@vims.edu).
}

Pacific Science (2015), vol. 69, no. 4:461-475 doi:10.2984/69.4.3 (Includes online supplements) (C) 2015 by University of Hawai'i Press

All rights reserved have been expanding and intensifying over the past 50 years due to anthropogenic influences, such as increasing industrial emissions, which are increasing global water temperatures and stratification (Stramma et al. 2008, Bertrand et al. 2010). Some of the largest OMZs are sustained in upwelling regions because upwelling introduces nutrients to surface waters, which support high levels of primary productivity and bacterial decomposition on sinking material that can induce hypoxia to form an OMZ (Levin 2003, Prince and Goodyear 2006, Bertrand et al. 2010). Other possible mechanisms leading to increased deoxygenation of oceanic water masses include surface layer warming, reduced oceanic mixing, and higher metabolic rates of organisms (Stramma et al. 2010).

The study of El Niño-Southern Oscillation (ENSO) phenomena has resulted in largescale studies of the Central Pacific Ocean to characterize the long-term variability of 
surface oceanographic conditions using an array of moored instruments (Lu et al. 2001, Trenberth and Smith 2006, Kao and Yu 2009). In general, La Niña events in the Central Pacific Ocean result in temperatures in the upper $150 \mathrm{~m}$ being $0.8^{\circ} \mathrm{C}$ cooler than in a normal year due to increased upwelling (Kao and $\mathrm{Yu} 2009$ ). Due to perturbations in the marine environment associated with climate change, the upper limit of the Equatorial $\mathrm{Pa}$ cific Ocean OMZ is becoming shallower (Bertrand et al. 2010, Stramma et al. 2010). This expansion of the $\mathrm{OMZ}$ may constrict the potential vertical habitat of organisms, which may result in a barrier to fishes and potential prey intolerant of hypoxic conditions (Bertrand et al. 2010). The reduction of available, well-oxygenated vertical habitats in the water column to the upper epipelagic zone can increase the vulnerability of pelagic fish populations to surface fishing gears, interspecific competition, habitat overlap with prey, and energetic costs related to foraging (Prince and Goodyear 2006; Zhang et al. 2009). In the Western and Central Pacific Ocean, there was an increase in the annual catches of yellowfin, bigeye, and Southern hemisphere albacore tuna by all gear types during the $2008 \mathrm{La}$ Niña event (Inter-American Tropical Tuna Commission 2013). One possible explanation for these increases in catches is the reduction of suitable vertical habitat available to these tunas during the La Niña event, though changes in horizontal distribution could have also occurred.

Tropical tunas (Family: Scombridae) are fast, continuously swimming teleosts that are also apex predators vital to the commercial long line and purse seine fishing industries of many nations in the Pacific Ocean, and they are at risk of vertical habitat compression events ( $\mathrm{Lu}$ et al. 2001, Wegner et al. 2010). The four most abundant and commercially important tuna species in the tropical Pacific Ocean are bigeye tuna (Thunnus obesus), skipjack tuna (Katsuwonus pelamis), yellowfin tuna (T. albacares), and albacore tuna (T. alalunga). These tunas exhibit systemic endothermy, a unique adaptation that allows them to regulate a body temperature higher than the ambient water temperature, although there are species-specific differences in the structure and efficiency of their endothermic systems (Brill 1994, Lu et al. 2001). However, endothermy, as well as high somatic and gonadal growth rates, elevates the metabolic demands of tunas, which increases their oxygen demand relative to other fishes (Wegner et al. 2010) and their potential sensitivity to OMZs.

Of the examined tuna species, adult bigeye tuna are able to tolerate the deepest and coldest waters because they are more efficient at retaining heat and oxygen (Brill 1994, Lowe et al. 2000, Graham and Dickson 2004) (Table 1). Adult albacore tuna (a subtropical tuna species) can tolerate colder water temperatures than yellowfin and skipjack tunas (Bernal et al. 2001, Graham and Dickson 2004, Chen et al. 2005); however, adult albacore tuna are less tolerant of hypoxic conditions than adult bigeye and yellowfin tunas (Bertrand, Josse et al. 2002).

In addition to their physiological tolerances, a tuna species' diving behavior is associated with the vertical distribution of their primary prey (Allain 2005). For example, albacore and bigeye tunas are deep-diving tunas due to their tolerances to low temperature and dissolved oxygen (DO) conditions and their diets are dominated by mesopelagic and bathypelagic prey. Skipjack tuna are not tolerant of low temperatures or DO levels, spending approximately $60 \%$ to $80 \%$ of their time within the surface mixed layer (upper $200 \mathrm{~m}$ ) and rarely diving below the thermocline (Schaefer and Fuller 2007; although

\section{TABLE 1}

Physiological and Comfort Values for Temperature and Dissolved Oxygen Used to Define the Potential Vertical Habitat of the Four Examined Tuna Species in the Central Pacific Ocean

\begin{tabular}{lrccc}
\hline \hline Species & $\begin{array}{c}\text { TPhy } \\
\left({ }^{\circ} \mathrm{C}\right)\end{array}$ & $\begin{array}{c}\text { TComfort } \\
\left({ }^{\circ} \mathrm{C}\right)\end{array}$ & $\begin{array}{c}\text { DOPhy } \\
(\mu \mathrm{mol} / \mathrm{kg})\end{array}$ & $\begin{array}{c}\text { DOComfort } \\
(\mu \mathrm{mol} / \mathrm{kg})\end{array}$ \\
\hline Bigeye & 8.0 & 12.0 & 26.1 & 139.5 \\
Skipjack & 11.0 & 22.0 & 89.3 & 176.0 \\
Yellowfin & 10.5 & 17.5 & 43.6 & 107.4 \\
Albacore & 10.0 & 18.0 & 65.4 & 162.8 \\
\hline
\end{tabular}

Note: $\mathrm{DO}=$ dissolved oxygen $; \mathrm{Phy}=$ physiological; $\mathrm{T}=$ temperature. 
these observations are only based on five tagged specimens). As expected, skipjack tuna feed almost exclusively in the epipelagic zone (Bertrand, Bard, and Josse 2002, Allain 2005). Similar to skipjack tuna, yellowfin tuna spend the majority of their time in the surface mixed layer with uniform temperatures and DO concentrations at or near saturation (Block et al. 1997, Swimmer et al. 2004). Although yellowfin are not able to physiologically thermoregulate as efficiently as bigeye tuna can, their behavior remains unaffected by low DO even after skipjack tuna behavior has been significantly altered (Brill 1994). Foraging on mesopelagic fishes and bathypelagic organisms has been observed in yellowfin tuna in addition to their typical diet dominated by epipelagic prey (Brill 1994, Bertrand, Bard, and Josse 2002, Allain 2005, Brill et al. 2005, Potier et al. 2007).

Few studies have associated vertical changes in temperature and DO, due to ENSO cycles, with the impacts that these oceanographic conditions may have on the potential vertical habitat of commercially important tuna species in the Central Pacific Ocean (Prince and Goodyear 2006, Bertrand et al. 2010). In addition, the effects of subsurface DO and temperature features on zooplankton and nekton distribution in the Central Pacific Ocean have rarely been examined in detail (Bertrand, Josse et al. 2002, Dagorn et al. 2006, Schaefer and Fuller 2007). In this study, we characterized vertical temperature and DO conditions in the Central Equatorial Pacific Ocean during the La Niña event in 2008, identified the geographic and vertical extent of OMZs, and assessed the potential vertical habitat of four commercially important tuna species in the Central Equatorial Pacific Ocean in relation to our oceanographic observations.

\section{MATERIALS AND METHODS}

\section{Oceanographic Data}

Observations of the physical marine environment for this study were collected aboard the SSV Robert $C$. Seamans, a sailing school vessel with deep deployment capabilities and a suite of remote sensing equipment that is owned and operated by the Sea Education Association (Woods Hole, MA). In 2008, data were collected during three cruises between Papeete, Tahiti (French Polynesia), and Honolulu, Hawai $i$. Exact cruise tracks were determined by meteorological conditions present during each cruise transect. The S215 cruise sailed from Tahiti to Hawai'i between 16 February and 16 March; the S216 cruise returned from Hawai'i to Tahiti between 30 March and 2 May; and the S217 cruise leg sailed from Tahiti to Hawai'i between 11 May and 12 June (Figure 1).

To examine temporal changes to temperature and DO, vertical profiles of temperature and DO were measured on each cruise by a Seabird SBE 19plus V2 Conductivity Temperature Depth (CTD) device equipped with a SBE 43 DO sensor. The CTD was deployed twice a day (approximately at noon and midnight), roughly $121 \mathrm{~km}$ apart, to a depth of $500 \mathrm{~m}$. Final temperature and DO data were postprocessed at $1 \mathrm{~m}$ intervals for S216 and $5 \mathrm{~m}$ intervals for S215 and S217.

Acoustic Doppler Current Profiler (ADCP) raw backscatter data and surface zooplankton density data were used to indicate areas with higher concentrations of potential tuna prey (Lara-Lopez and Neira 2008, Burd and Thomson 2012). Acoustic samples were collected with a hull-mounted RDI Ocean Surveyor ADCP $(75 \mathrm{kHz})$ and these data were averaged every $20 \mathrm{~min}$ with a bin length of $10 \mathrm{~m}$ to a depth of approximately $600 \mathrm{~m}$. The acoustic reflectance data were used to describe the deep scattering layer and other areas of high backscatter, which can correlate with high planktonic biomass (Fielding et al. 2004, Burd and Thomson 2012). To account for day and night differences of the deep scattering layer, day and night ADCP data were examined separately. Daytime was defined as the hours between 0800 and 1700 and nighttime was defined as the hours between 2000 and 0500 in order to remove the effects of transitional periods (Domokos et al. 2007). To characterize the planktonic community, planktonic organisms were sampled twice a day (at noon and midnight) with a neuston net $(1 \times 0.5 \mathrm{~m}$ wide opening; $335 \mu \mathrm{m}$ mesh) towed 


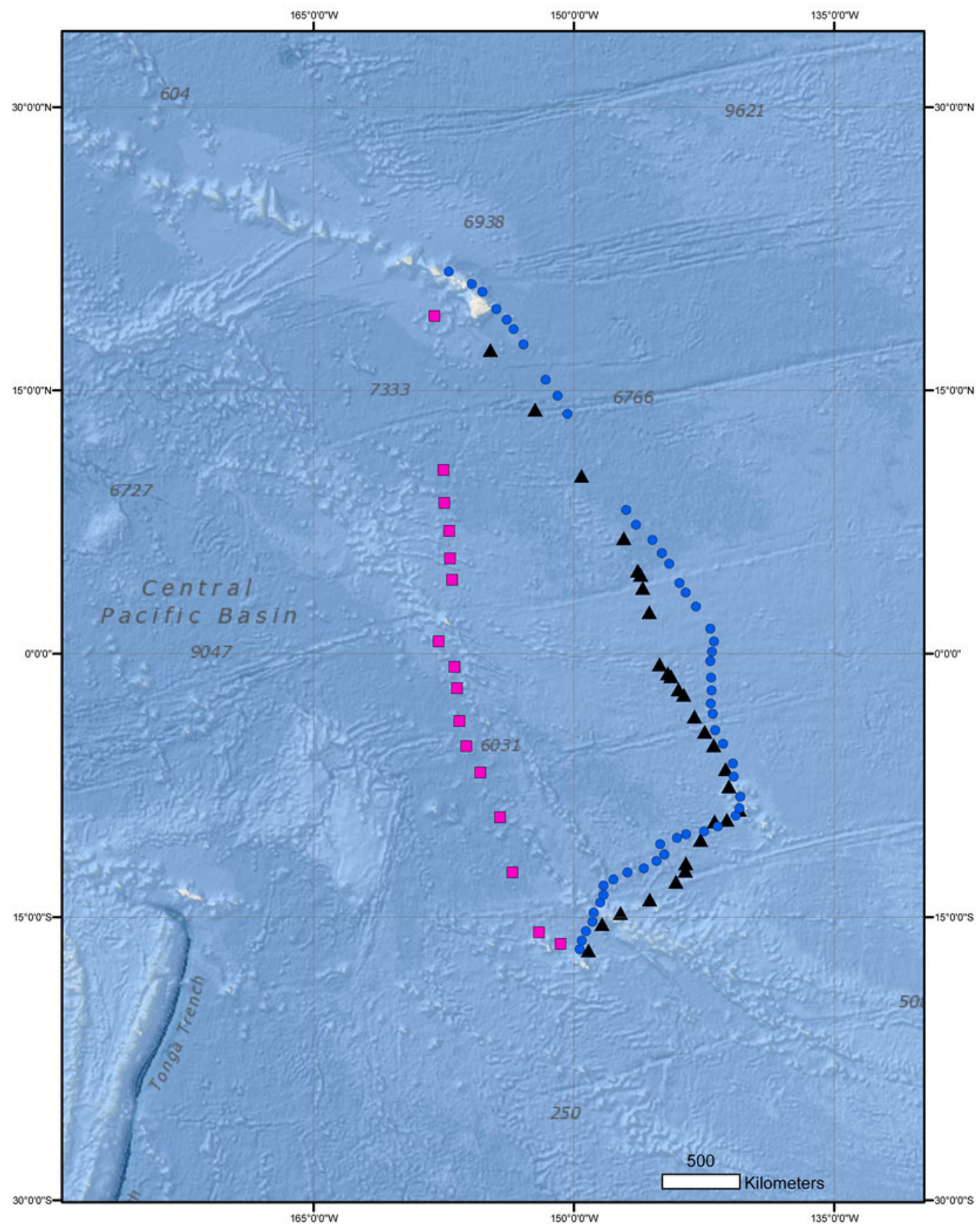

Figure 1. Map of the three 2008 Sea Education Association cruise transects between Hawai'i and Tahiti. Symbols indicate zooplankton and CTD sampling stations corresponding to the February-March (triangles), March-May (squares), and May-June (circles) transects. 
at the air-sea interface for approximately 1 nautical mile $(1.85 \mathrm{~km})$ for all three cruises. GPS locations were used to determine the tow volume and tow distance for the neuston net. Myctophid fishes were sorted from the zooplankton samples and counted. Myctophid fishes were separated from the samples because they are a common mesopelagic fish family and are consistently found in the diets of yellowfin, bigeye, and albacore tunas (Bertrand, Bard, and Josse 2002, Allain 2005, Potier et al. 2007). Zooplankton density was determined by dividing volumetrically displaced mass by tow distance, and myctophid fish densities were calculated separately by dividing myctophid counts by tow distance.

\section{Hydrographic Preferences of Tunas}

Temperature and DO limit estimations for the four examined tuna species were based on adult and juvenile specimens from the work of Bertrand, Josse et al. (2002) and Brill (1994) (Table 1). The specific physiological vertical habitat $(\mathrm{PVH})$ was defined as the depth at the lower limits of the temperature or DO tolerances reported for the adults from each species of tuna. For bigeye, yellowfin, and albacore tunas, the temperature and DO conditions used to predict PVH was estimated based on where $<2.5 \%$ of longline catches occurred in Bertrand, Josse et al. (2002) (Table 1). Their study had large sample sizes ( $\geq 100$ individuals) of albacore, bigeye, and yellowfin tunas but collected no skipjack (Bertrand, Josse et al. 2002). Brill (1994) experimentally estimated physiological DO limits for bigeye, yellowfin, and albacore that were approximately twice the limits defined by Bertrand, Josse et al.'s (2002) in-situ catch data (Table 1), which suggest a possible disconnect between distribution of longline tuna catches and tuna distribution. Given the consistent DO limit relationship found between the Brill (1994) and Bertrand, Josse et al. (2002) studies for albacore, bigeye, and yellowfin, we estimated the DO PVH limit for skipjack tuna to be half of the DO limit measured by Brill (1994). The temperature PVH limit for skipjack tuna was obtained from two tagging studies (Ogura 2003, Schaefer et al. 2009) (Table 1).

The comfort vertical habitat $(\mathrm{CVH})$ of a tuna species was defined as the portion of the water column where a tuna spends $>50 \%$ of its time and is within the preferred temperature and DO ranges of that species based on previous studies. Therefore, CVH is an approximation of the preferred habitat conditions for each tuna species and attempts to describe the habitat where tunas spend the majority of their time. The CVH was defined for bigeye as the temperature and DO conditions most frequently observed in tagged and longline bigeye captures (Dagorn et al. 2000, Bach et al. 2003, Evans et al. 2008) (Table 1). Lower limits of the CVH for yellowfin tuna were defined as temperature and DO concentrations corresponding to highest observed longline catch rates, which may indicate the lower limit of oceanographic conditions within the preferred conditions (Song et al. 2008). The temperature $\mathrm{CVH}$ was also corroborated by tagging study that recorded a similar temperature range (Block et al. 1997) (Table 1). For albacore tuna, the DO where swimming behavior was observed to be negatively impacted under controlled conditions was selected as the DO CVH limit (Brill 1994), whereas the temperature $\mathrm{CVH}$ limit was determined from observations collected via electronic tag deployments (Williams et al. 2015). The DO CVH limit for skipjack tuna was estimated from the DO level at which venous oxygen content significantly decreased in skipjack individuals under laboratory conditions (Brill 1994) and the temperature CVH limit was estimated from a tagging study (Schaefer and Fuller 2007) (Table 1).

\section{RESULTS}

\section{Oceanographic Data}

All three cruises occurred during a La Niña period, although February had the highest Southern Oscillation Index value at $21.3(\mathrm{Bu}-$ reau of Meteorology 2012) (Figure 2). Water temperatures in the upper $100 \mathrm{~m}$ were approximately $30^{\circ} \mathrm{C}$ in the Southern hemisphere stations relative to $25^{\circ} \mathrm{C}$ in the Northern 


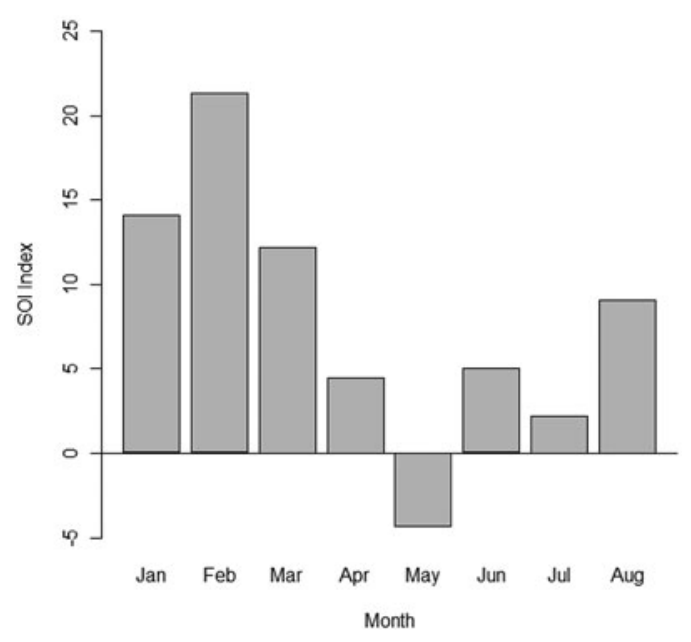

Figure 2. Southern Oscillation Index (SOI) by month over the study period in 2008. Positive numbers indicate La Niña conditions and negative numbers indicate El Niño conditions with the value corresponding to the strength of the conditions. Data from Bureau of Meteorology (2012).

hemisphere stations for all three transects (Figure S1 [available online from www. BioOne.org]). The thermocline shoaled to approximately $150 \mathrm{~m}$ between $5^{\circ} \mathrm{S}$ to $15^{\circ} \mathrm{N}$ during February to March and May to June, but between March and May, the shallowest thermocline was observed at $100 \mathrm{~m}$ near $10^{\circ} \mathrm{N}$ (Figure S1).

Generally, DO concentrations were greater in the Southern hemisphere stations relative to the Northern hemisphere stations (Figure $\mathrm{S} 1)$. There was an $\mathrm{OMZ}(<23.3 \mu \mathrm{mol} / \mathrm{kg})$ present between $5^{\circ} \mathrm{N}$ and $15^{\circ} \mathrm{N}$ between February and March, extending approximately $1,280 \mathrm{~km}$ in width and with an upper boundary at $175 \mathrm{~m}$. In the Southern hemisphere, a small OMZ was present $(282 \mathrm{~km}$ wide; extending $250-425 \mathrm{~m}$ deep) with subsurface DO concentrations of approximately $50 \mu \mathrm{mol} / \mathrm{kg}$ between $10^{\circ} \mathrm{S}$ and the equator below $150 \mathrm{~m}$ (Figure S1). Between March and May, subsurface DO concentrations were $>100 \mu \mathrm{mol} / \mathrm{kg}$ between $10^{\circ} \mathrm{S}$ and $4^{\circ} \mathrm{S}$ throughout the water column, and the Northern hemisphere $\mathrm{OMZ}$ was not as extensive, ranging between $2^{\circ} \mathrm{N}$ and $15^{\circ} \mathrm{N}(787 \mathrm{~km}$ wide; upper limit of $150 \mathrm{~m}$ ). From May to June, a Southern and a Northern hemisphere $\mathrm{OMZ}$ was observed between $10^{\circ} \mathrm{S}$ and $4^{\circ} \mathrm{S}$ (692 km wide; upper limit of $175 \mathrm{~m}$ ) and between $5^{\circ} \mathrm{N}$ and $20^{\circ} \mathrm{N}(1,812 \mathrm{~km}$ wide; upper limit of $100 \mathrm{~m}$ ), respectively (Figure S1).

\section{Projected Vertical Tuna Habitat}

Potential vertical habitat of the four examined tuna species in the Central Pacific Ocean was mainly limited by DO (Figure 3), though temperature also limited potential vertical habitat, especially for yellowfin tuna $\mathrm{CVH}$. Following the patterns observed in the oceanographic data, the predicted vertical tuna CVH and PVH were more restricted in the Northern hemisphere stations than in the Southern hemisphere stations for all tuna species. The DO CVH was restricted to the upper $150 \mathrm{~m}$ between $5^{\circ} \mathrm{S}$ and $10^{\circ} \mathrm{N}$ from February to March, to the upper $200 \mathrm{~m}$ between $5^{\circ} \mathrm{S}$ and $10^{\circ} \mathrm{N}$ from March to May and to the upper $125 \mathrm{~m}$ between $2^{\circ} \mathrm{S}$ and $6^{\circ}$ $\mathrm{N}$ from May to June for all species except for yellowfin tuna near the equator $(200 \mathrm{~m}, 300 \mathrm{~m}$, $250 \mathrm{~m}$, respectively) (Figure 3). Unlike the $\mathrm{CVH}, \mathrm{PVH}$ for all tuna species was most restricted during February and March between $5^{\circ} \mathrm{S}$ and $1^{\circ} \mathrm{N}$ and between $4^{\circ} \mathrm{N}$ and $10^{\circ} \mathrm{N}$. During all three cruises, there was a deepening of PVH between $1^{\circ} \mathrm{S}$ and $1^{\circ} \mathrm{N}$.

Yellowfin tuna potential vertical habitat was limited primarily by temperature with some exceptions in the latitudes on either side of the equator for all three cruises (Figures 3-5). Bigeye tuna had a more extensive PVH that could be limited by either temperature or DO depending on the hydrographic conditions (Figures 3 and 4). Albacore tuna had a deeper predicted temperature PVH relative to yellowfin and skipjack but due to their DO sensitivities, their vertical habitat was restricted to a shallower depth by DO (Figures 3-5). Of the examined tuna species, skipjack tuna had the most restricted temperature and DO potential vertical habitat based on the observed oceanographic conditions in the Central Pacific Ocean. 
$\mathrm{CVH}(\mathrm{DO})$

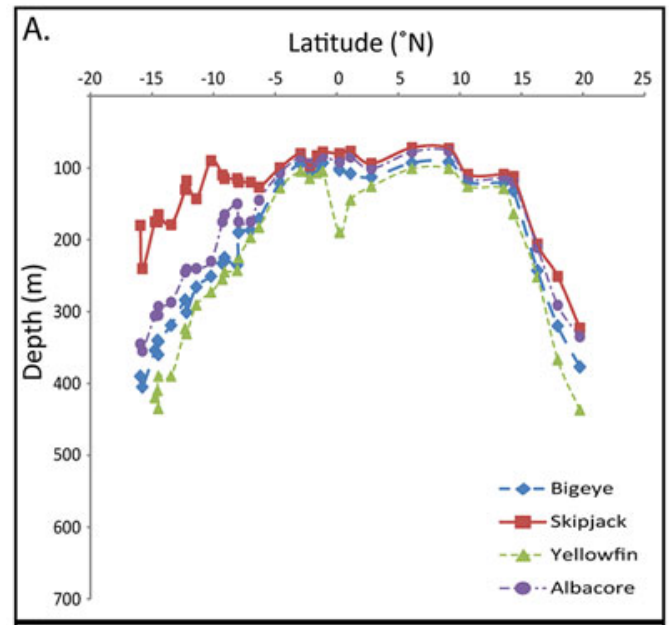

C.

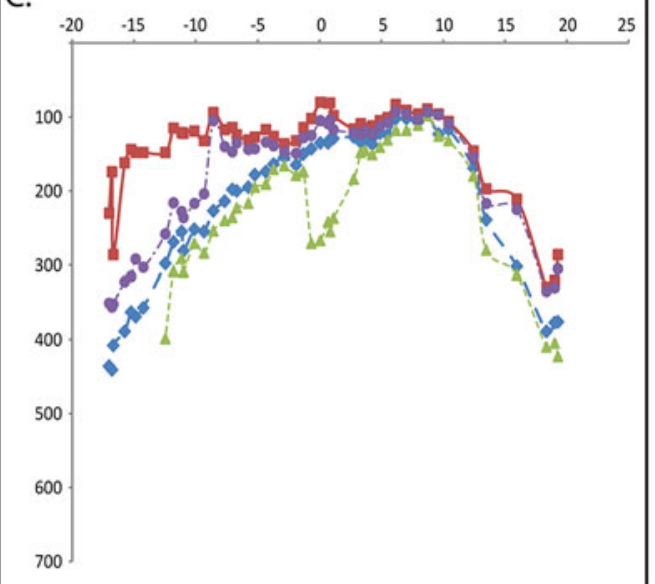

E.

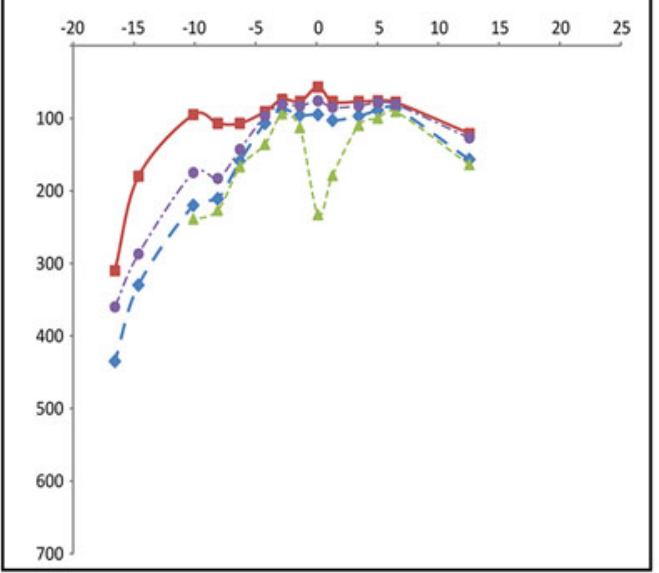

$\mathrm{PVH}(\mathrm{DO})$
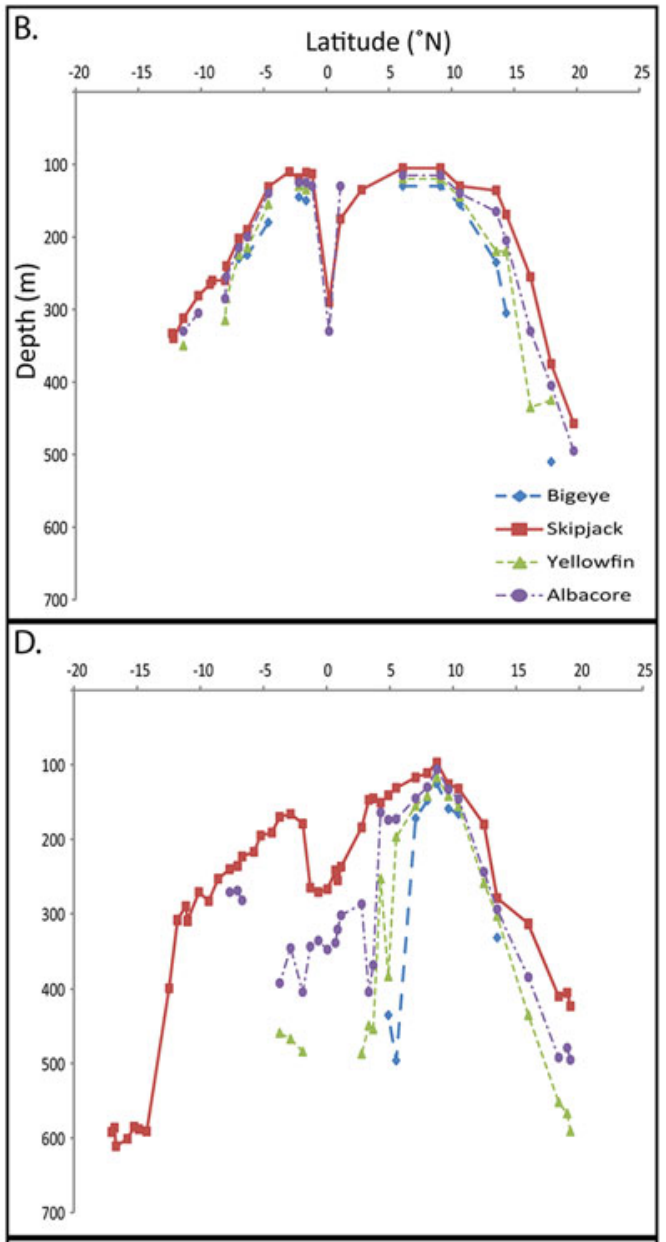

F.

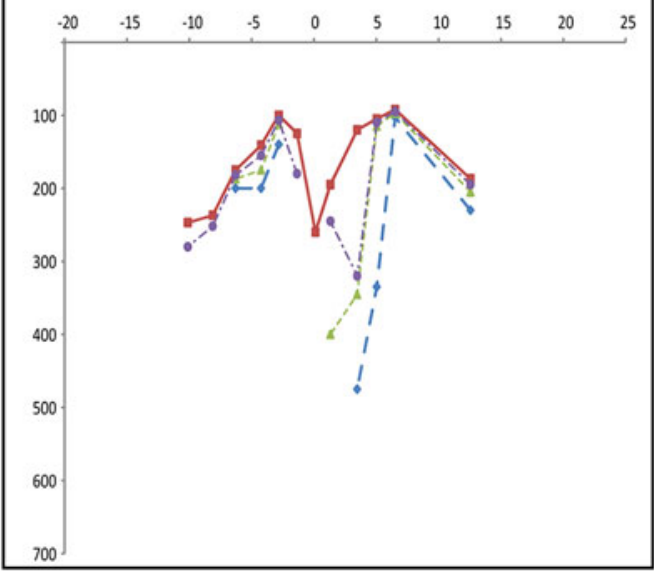

FIGURE 3. Potential lower boundary of vertical habitat of bigeye (diamond; dashed), skipjack (square; solid), yellowfin (triangle; dashed), and albacore (circle; dot-dash) tunas based on dissolved oxygen (DO) tolerances during the February-March $(A, B)$, March-May $(C, D)$, and May-June $(E, F)$ transects. Comfort vertical habitat $(C V H)$ is on the left and the physiological vertical habitat $(\mathrm{PVH})$ is on the right. 
CVH (T)

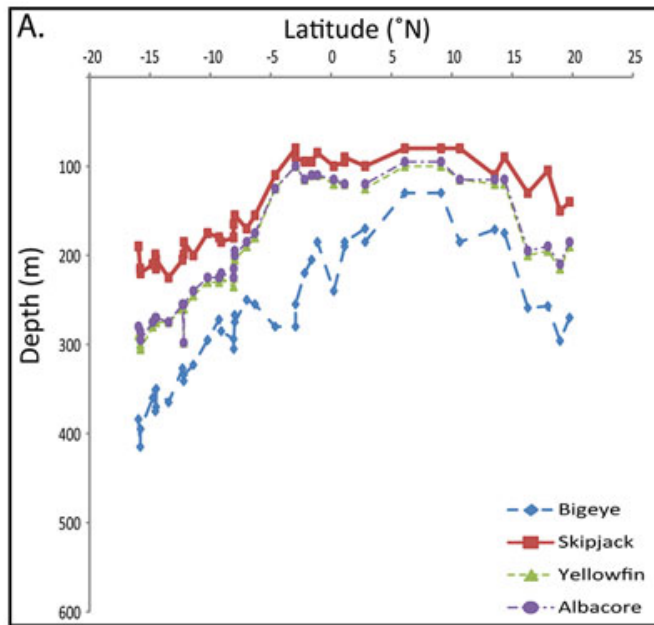

C.

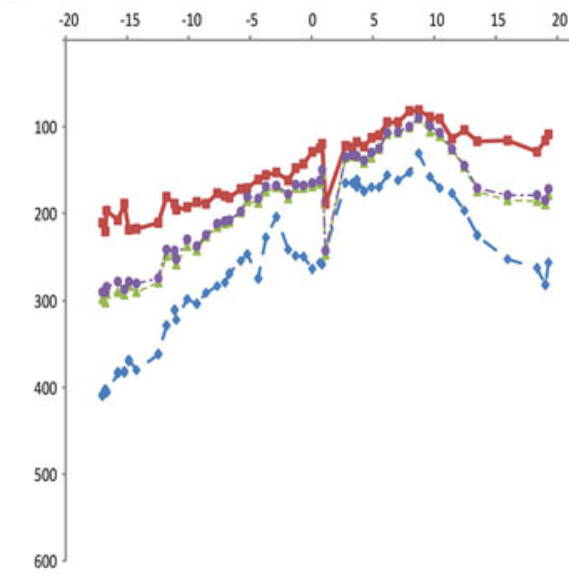

E.

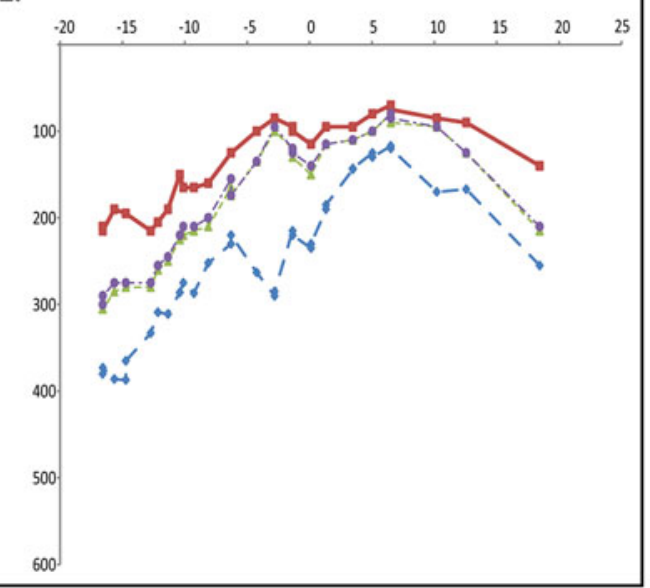

PVH (T)

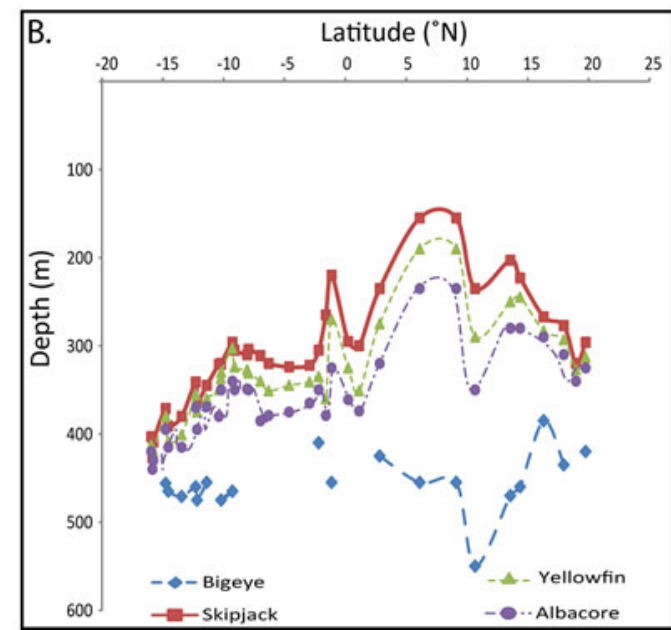

D.

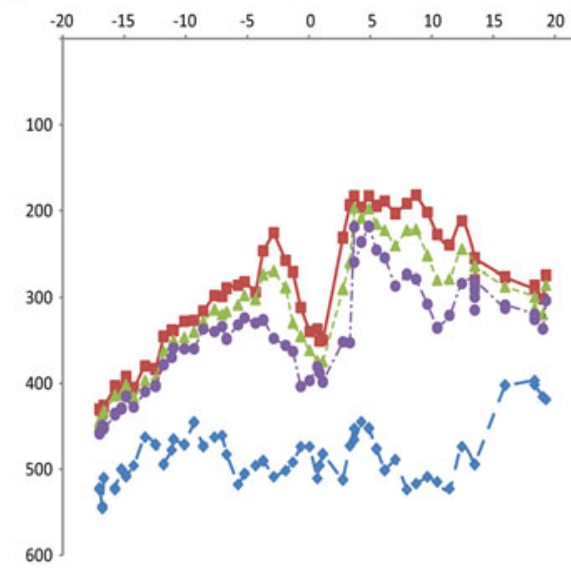

F.

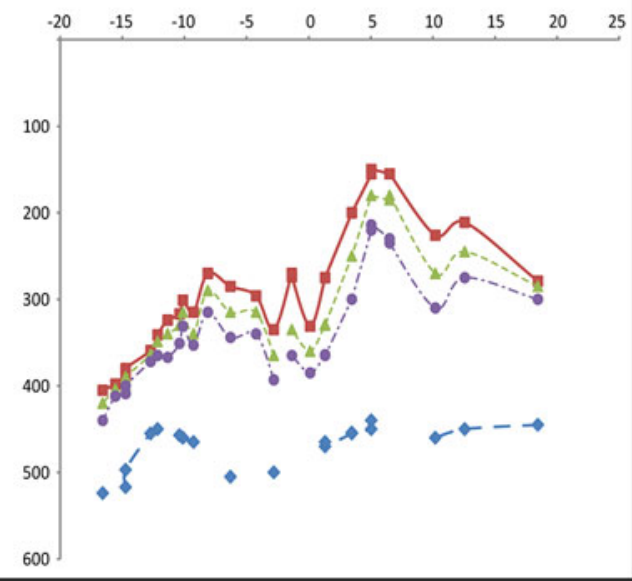

Figure 4. Potential lower boundary of vertical habitat of bigeye (diamond; dashed), skipjack (square; solid), yellowfin (triangle; dashed), and albacore (circle; dot-dash) tunas based on temperature (T) tolerances during the Febru$\operatorname{ary}-$ March $(A, B)$, March-May $(C, D)$, and May-June $(E, F)$ transects. Comfort vertical habitat $(C V H)$ is on the left and the physiological vertical habitat $(\mathrm{PVH})$ is on the right. 

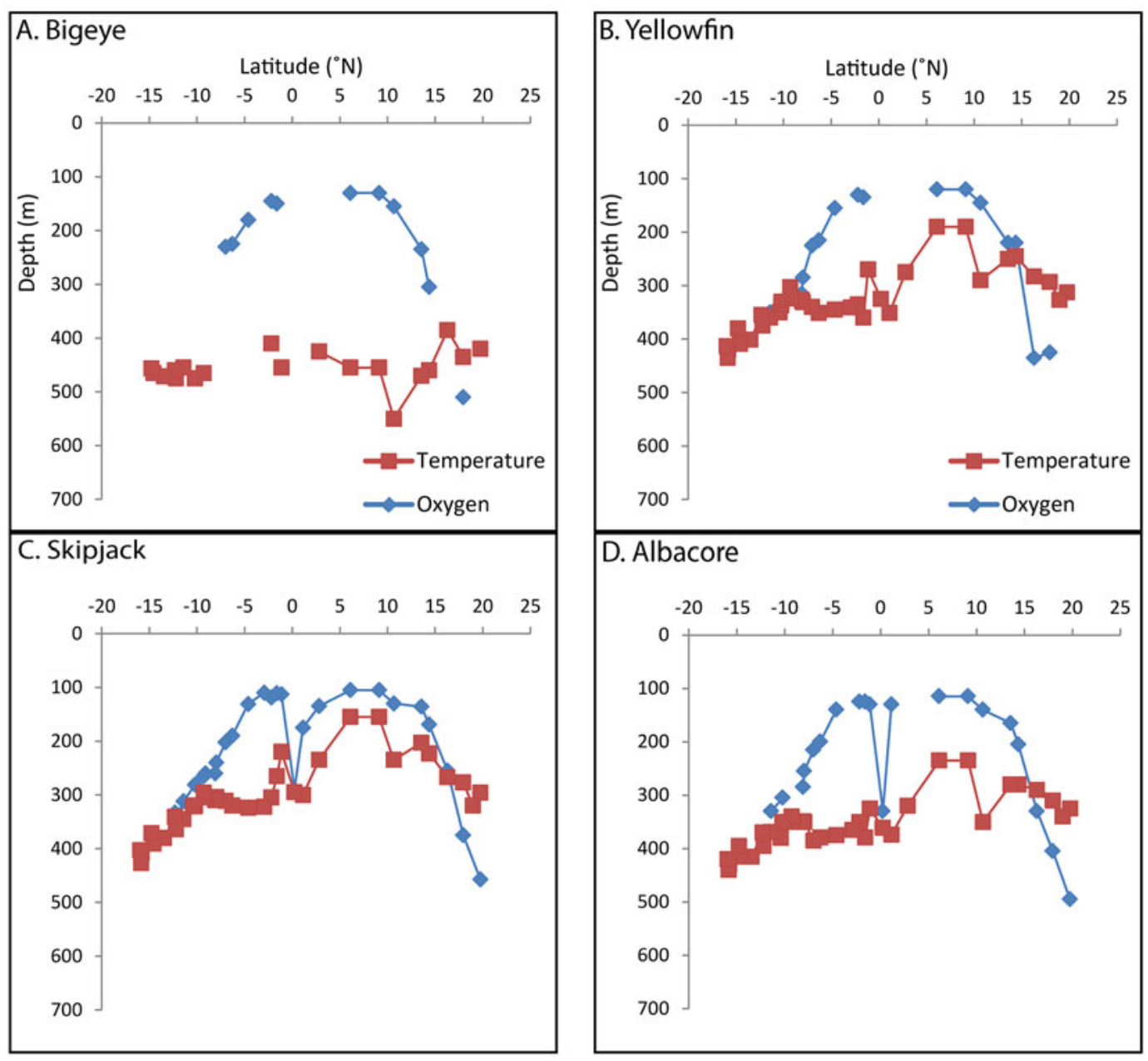

FIGURE 5. Comparison of physiological vertical habitat as delimited by dissolved oxygen (diamonds) and temperature (squares) for bigeye $(A)$, yellow fin $(B)$, skipjack $(C)$, and albacore $(D)$ tunas between February and March.

\section{Potential Prey}

ADCP backscatter echo counts were highest during both the day and night between $3^{\circ} \mathrm{S}$ and $7^{\circ} \mathrm{N}$ (175-200 counts) in the upper $50 \mathrm{~m}$ from February to May (Figure S2 [available online from www.BioOne.org]). However, between May and June, echo counts (175-200 counts) were more restricted vertically and horizontally, with the highest counts found between $3^{\circ} \mathrm{S}$ and $5^{\circ} \mathrm{N}$ in the upper $25 \mathrm{~m}$ (Figure S2). Echo counts were also higher in the Southern hemisphere relative to the
Northern hemisphere during all three cruises, especially between 150 and $225 \mathrm{~m}$ in depth. In this depth range, the echo counts in the Northern hemisphere were lower (approximately 50 counts) compared with those in the Southern hemisphere (75-80 counts) for all three cruises. In addition, zooplankton densities from net tows were highest between $10^{\circ} \mathrm{S}$ and $7^{\circ} \mathrm{N}$ in all three cruises, paralleling backscatter data (Figure 6). The density of myctophid fishes was greatest between $3^{\circ} \mathrm{S}$ and $7^{\circ} \mathrm{N}$, similar to what was observed in the ADCP data. 


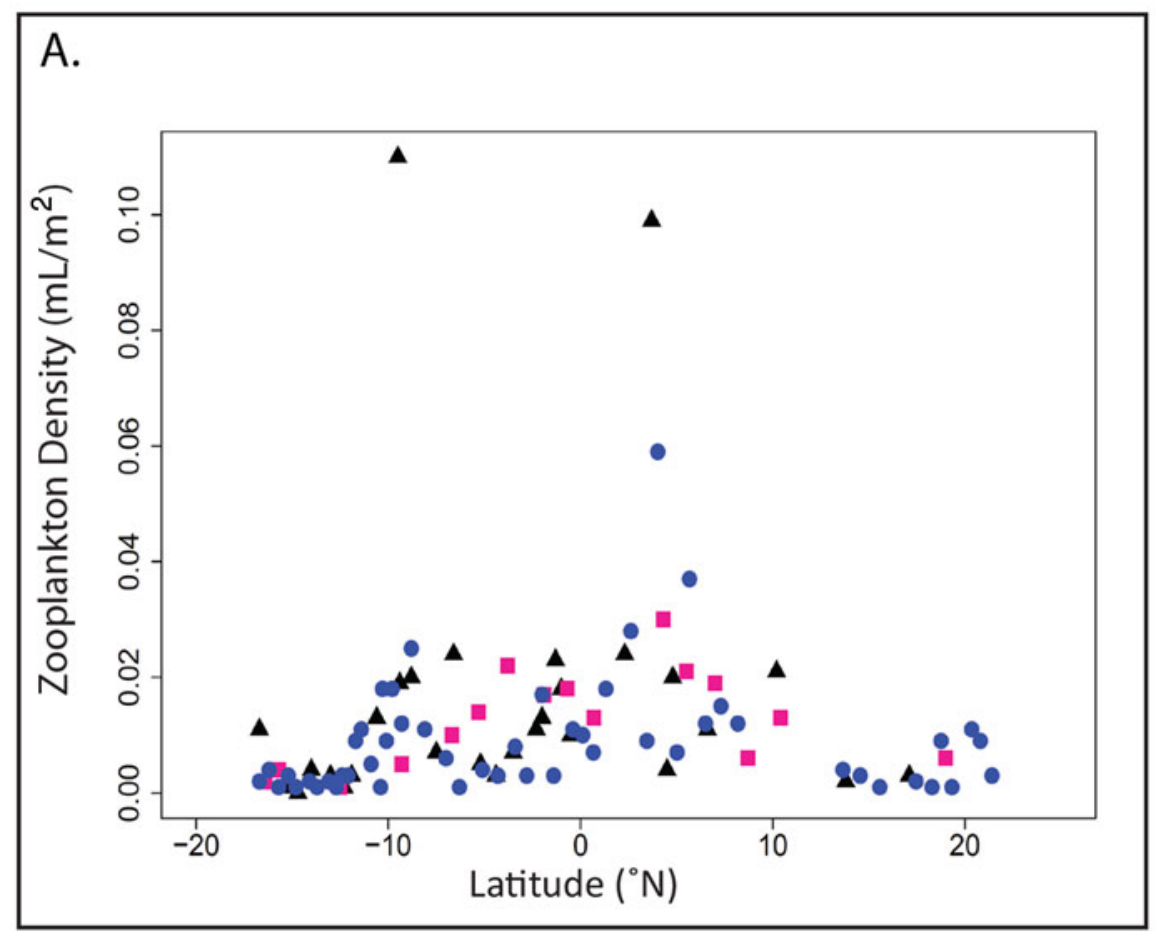

$\boldsymbol{\Delta}$ February-March $\mathbf{\square}$ March-May $\bullet$ May-June

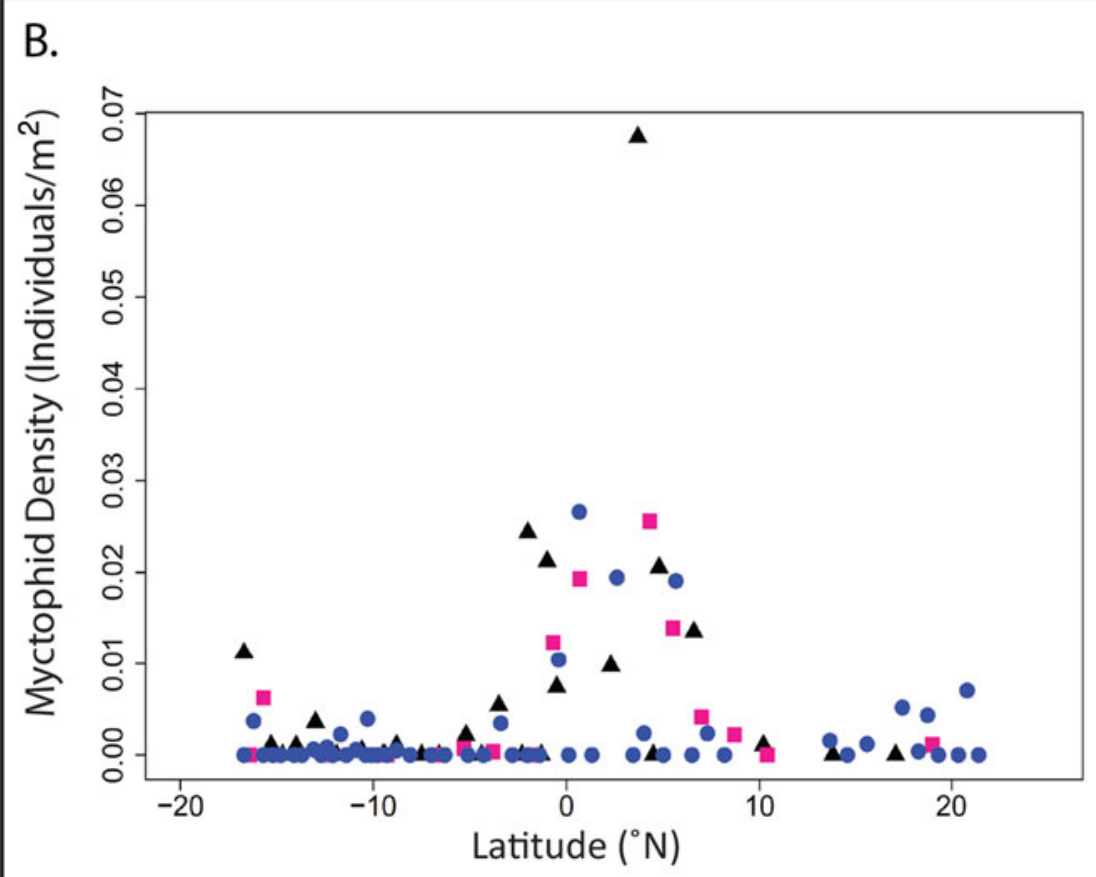

FIGURE 6. Zooplankton density $(A)$ and myctophid density $(B)$ during three transects in the Central Pacific Ocean in 2008: February-March (triangles); March-May (squares); May-June (circles). 
DISCUSSION

The primary goal of this study was to use observations of oceanographic conditions to infer the potential vertical habitat of four commercially important tropical tuna species in the Central Pacific Ocean. Both subsurface DO and temperature are important variables when predicting regions of suitable vertical habitat for these four tuna species. The examined tuna species are able to conserve heat produced during metabolism, but there are species-specific differences in the overall efficiency of the heat exchangers and an overall cost of systemic endothermy is elevated oxygen demands (Graham and Dickson 2004). Our understanding of the physiological tolerances of these four tuna species is incomplete, so our assessments of potential tuna distributions are rough predictions based on current knowledge.

In the Central Pacific, the estimated values of PVH and CVH suggest that DO restricts the potential vertical habitat distribution of tuna more than temperature. However, temperature is the most commonly used oceanographic variable to forecast tuna distribution (Andrade 2003). Yellowfin tuna are sensitive to low temperatures that accompany upwelling events, such as the $2008 \mathrm{La}$ Niña, and their estimated $\mathrm{CVH}$ was limited primarily by temperature, suggesting that thermoregulation may not be as efficient in yellowfin as it is in bigeye and albacore (Brill 1994, Graham and Dickson 2004). However, yellowfin tuna are tolerant to low DO levels (Brill 1994, Bertrand, Josse et al. 2002, Song et al. 2008) and had a DO CVH deeper than bigeye tuna, with the caveat that this difference may also be attributed to how the CVH was estimated for the four tuna species in this study. Bigeye tuna are the most tolerant of all the examined species to low temperatures, resulting in a more extensive predicted PVH limited by temperature or DO depending on the oceanographic conditions. Albacore tuna are more tolerant of low temperatures relative to yellowfin and skipjack tunas and had a deeper PVH estimated by temperature. However, albacore tuna are not as tolerant to low DO levels and their potential vertical habitat was limited by DO. Skipjack tuna are the least tolerant to low temperatures and DO levels, and therefore were predicted to have the most restricted vertical habitat between February and June in the Central Pacific Ocean. The PVH determined by temperature and DO profiles is always deeper than the CVH. However, between $5^{\circ}$ and $10^{\circ} \mathrm{N}$, the $\mathrm{OMZ}$ reached a minimum in the upper $200 \mathrm{~m}$, creating a significant barrier to the four tunas and resulting in the overlap of $\mathrm{PVH}$ and $\mathrm{CVH}$ in all three transects.

As the Southern Oscillation Index value decreased from February to March (Bureau of Meteorology 2012), the OMZ decreased both horizontally and vertically in size while the thermocline increased in depth. During these months, the estimated PVH of all four tuna species were less restrictive and expanded vertically and horizontally. Between May and June, an OMZ in the Southern hemisphere was observed, but it did not extend as deep or wide as the more homogeneous Northern hemisphere OMZ. On the basis of the estimated PVH and CVH, the Northern hemisphere OMZ likely constituted a significant barrier to even the more hypoxia-tolerant tuna species such as yellowfin and bigeye. Between $0^{\circ}$ and $5^{\circ} \mathrm{N}$, the estimated $\mathrm{PVH}$ deepened for all the examined tunas due to an increase in DO. Based on their specific physiological capabilities, this may have allowed yellow fin and bigeye to dive deeper and exploit deeper vertical habitats than skipjack and albacore. It should be recognized that although the estimated vertical habitat was expanded due to increased DO concentrations between $0^{\circ}$ and $5^{\circ} \mathrm{N}$, the thermocline remained shallow and the physiological thermal minimum of yellowfin, skipjack, and albacore was reached at $300-350 \mathrm{~m}$ between February and March, $375 \mathrm{~m}$ from March to May, and 350-400 $\mathrm{m}$ between May and June (Figure 4). Under these oceanographic conditions, the predicted vertical habitat of yellowfin, skipjack, and albacore were not exclusively limited by DO, but also by temperature between $0^{\circ}$ and $5^{\circ} \mathrm{N}$ (Figure 5).

ADCP echo counts were high in the upper $50 \mathrm{~m}$ during all three cruises between $3^{\circ} \mathrm{S}$ and $5^{\circ} \mathrm{N}$ regardless of time of day, which also 
corresponded to the region where relative zooplankton and myctophid densities collected from net tows peaked in the upper $200 \mathrm{~m}$. This suggests that upwelling related to the La Niña event increased secondary productivity (echo counts $>175)$ and potential prey in the upper $200 \mathrm{~m}$ (Bertrand, Bard, and Josse 2002, Allain 2005, Scholz et al. 2011), which coincided with the predicted $\mathrm{CVH}$ and $\mathrm{PVH}$ of all four tuna species. Upwelling was directly observed during all three cruises and is reflected in the temperature profiles. Between March and June, the $2008 \mathrm{La}$ Niña event brought cold $\left(10^{\circ} \mathrm{C}-\right.$ $15^{\circ} \mathrm{C}$ ), deep water to the upper $200 \mathrm{~m}$ of the ocean around the equator and surrounding areas $\left(10^{\circ} \mathrm{S}\right.$ to $\left.10^{\circ} \mathrm{N}\right)$. These latitudes also correspond to the region with the most severe projected vertical habitat restriction for the examined tuna species.

The colder, upwelled water induces $\mathrm{OMZs}$ below the thermocline due to the bacterial decay of large amounts of sinking biological material (Prince and Goodyear 2006). During an El Niño year, upwelling is minimal, resulting in increased stratification, a deeper thermocline, and reduced nutrient input into the upper layers (Levin 2003, Scholz et al. 2011) of the Central Pacific Ocean between $10^{\circ} \mathrm{S}$ and $10^{\circ} \mathrm{N}$. Based on the physiological tolerances of the examined tunas, it is expected that the potential vertical habitat restrictions during El Niño conditions would be reduced due to smaller and deeper OMZs and a deeper thermocline, therefore allowing tuna to vertically partition their habitat. It is expected that in an El Niño year, skipjack would possess the shallowest CVH due to their low temperature and DO tolerances, followed by yellowfin, albacore, and bigeye based on their physiological capabilities (Brill 1994, Bertrand, Josse et al. 2002, Schaefer and Fuller 2007). However, during La Niña years when the potential vertical habitat is restricted and there are expected overlaps between the vertical habitat ranges of these tuna species, increased competition for prey could be balanced by the associated increase in secondary production, especially in the upper $200 \mathrm{~m}$. Another possible consequence of tunas encountering unsuitable oceanographic conditions at depth is that they may undergo horizontal migrations to escape these conditions (Lehodey et al. 1997, Lu et al. 2001, Ganachaud et al. 2013).

Based on the oceanographic conditions observed during the 2008 La Niña, the predicted vertical habitat was expected to be vertically restricted for the four tunas, especially in the latitudes adjacent to the equator in the Northern and Southern hemispheres. If tunas do not horizontally migrate from these areas with unsuitable oceanographic conditions, habitat compression due to expanding OMZs and a shallower thermocline could result in tunas possibly not being able to avoid longline and purse seine fishing gears (Andrade 2003, Prince and Goodyear 2006, Zhang et al. 2009). Therefore, during La Niña conditions, all four tuna species are potentially more vulnerable to capture by surface fishing gears, even if depth selective gear deployment schemes are employed to reduce tuna bycatch in the region between $5^{\circ} \mathrm{S}$ and $10^{\circ} \mathrm{N}$ (Bigelow et al. 2006, Beverly et al. 2008). Local extirpation is another potential impact of low temperature and DO conditions related to La Niña events due to the highly migratory nature of these tuna species (Graham and Dickson 2004). Further understanding of the relationship between oceanographic conditions, particularly DO and temperature during different ENSO cycles may allow us to make better predictions regarding suitable vertical habitat usage of target species.

\section{ACKNOWLEDGMENTS}

We are grateful for the work of the Sea Education Association (www.sea.edu), especially the crew of the SSV Robert C. Seamans, for tirelessly collecting oceanographic data and providing unique research opportunities to undergraduate students.

\section{Literature Cited}

Allain, V. 2005. Diet of four tuna species of the Western and Central Pacific Ocean. SPC Fish. Newsl. 114:30-33.

Andrade, H. A. 2003. The relationship between the skipjack tuna (Katsuwonus pela- 
mis) fishery and seasonal temperature variability in the south-western Atlantic. Fish. Oceanogr. 12:10-18.

Bach, B., L. Dagorn, A. Bertrand, E. Josse, and C. Misselis. 2003. Acoustic telemetry versus monitored longline fishing for studying the vertical distribution of pelagic fish: Bigeye tuna (Thunnus obesus) in French Polynesia. Fish. Res. 60:281-292.

Bernal, D., K. A. Dickson, R. E. Shadwick, and J. B. Graham. 2001. Review: Analysis of the evolutionary convergence for high performance swimming in lamnid sharks and tunas. Comp. Biochem. Physiol. A 129:695-726.

Bertrand, A., M. Ballón, and A. Chaigneau. 2010. Acoustic observation of living organisms reveals the upper limit of the Oxygen Minimum Zone. PLoS ONE 5 (4): 1-9.

Bertrand, A., F. X. Bard, and E. Josse. 2002. Tuna food habits related to the micronekton distribution in French Polynesia. Mar. Biol. 140:1023-1037.

Bertrand, A., E. Josse, P. Bach, P. Gros, and L. Dagorn. 2002. Hydrological and trophic characteristics of tuna habitat: Consequences on tuna distribution and longline catchability. Can. J. Fish. Aquat. Sci. 59:1002-1013.

Beverly, S., D. Curran, M. Musyl, and B. Molony. 2008. Effects of eliminating shallow hooks from tuna longline sets on target and non-target species in the Hawaii-based pelagic tuna fishery. Fish. Res. 96:281-288.

Bigelow, K., M. K. Musyl, F. Poisson, and P. Kleiber. 2006. Pelagic longline gear depth and shoaling. Fish. Res. 77:173-183.

Block, B. A., J. E. Keen, B. Castillo, H. Dewar, E. V. Freund, D. J. Marcinek, R. W. Brill, and C. Farwell. 1997. Environmental preferences of yellowfin tuna (Thunnus albacares) at the northern extent of its range. Mar. Biol. 130:119-132.

Brill, R. W. 1994. A review of temperature and oxygen tolerance studies of tunas pertinent to fisheries oceanography, movement models and stock assessments. Fish. Oceanogr. 3 (3): 204-216.

Brill, R. W., K. A. Bigelow, M. K. Musyl, K. A. Fritsches, and E. J. Warrant. 2005. Bigeye tuna (Thunnus obesus) behavior and physiology and their relevance to stock assessments and fishery biology. Col. Vol. Sci. Pap. ICCAT 57 (2): 142-161.

Burd, B. J., and R. E. Thomson. 2012. Estimating zooplankton biomass distribution in the water column near the Endeavour Segment of Juan de Fuca Ridge using acoustic backscatter and concurrently towed nets. Oceanography 25 (1): 269-276.

Bureau of Meteorology. 2012. S.O.I. (Southern Oscillation Index) Archives-1876 to present. Australian Government. Accessed 8 August 2012. http://www.bom.gov.au /climate/current/soihtm1.shtml.

Chen, I. C., P .F. Lee, and W. N. Tzeng. 2005. Distribution of albacore (Thunnus alalunga) in the Indian Ocean and its relation to environmental factors. Fish. Oceanogr. 14 (1): 71-80.

Dagorn, L., P. Bach, and E. Josse. 2000. Movement patterns of large bigeye tuna (Thunnus obesus) in the open ocean, determined using ultrasonic telemetry. Mar. Biol. 136:361-371.

Dagorn, L., K. N. Holland, J. P. Hallier, M. Taquet, G. Moreno, G. Sancho, D. G. Itano, R. Aumeeruddy, C. Girard, J. Million, and A. Fonteneau. 2006. Deep diving behavior observed in yellowfin tuna (Thunnus albacares). Aquat. Living Resour. 19:85-88.

Domokos, R., M. P. Seki, J. J. Polovina, and D. R. Hawn. 2007. Oceanographic investigation of the American Samoa albacore (Thunnus alalunga) habitat and longline fishing grounds. Fish. Oceanogr. 16 (6): 555-572.

Evans, K., A. Langley, N. P. Clear, P. Williams, T. Patterson, J. Sibert, J. Hampton, and J. S. Gunn. 2008. Behaviour and habitat preferences of bigeye tuna (Thunnus obesus) and their influence on longline fishery catches in the western Coral Sea. Can. J. Fish. Aquat. Sci. 65:2427-2443.

Fielding, S., G. Griffiths, and H. S. J. Roe. 2004. The biological validation of ADCP acoustic backscatter through direct comparison with net samples and model predictions based on acoustic-scattering models. ICES J. Mar. Sci. 61:184-200. 
Ganachaud, A., A. S. Gupta, J. N. Brown, K. Evans, C. Maes, L. C. Muir, and F. S. Graham. 2013. Projected changes in the tropical Pacific Ocean of importance to tuna fisheries. Clim. Change 119:163-179.

Graham, J. B., and K. A. Dickson. 2004. Tuna comparative physiology. J. Exp. Biol. 207:4015-4024.

Inter-American Tropical Tuna Commission. 2013. The fishery for tunas and billfishes in the Eastern Pacific Ocean in 2012. Scientific Advisory Committee 4th meeting. 29 April-3 May 2013, La Jolla, California.

Kao, H. Y., and J. Y. Yu. 2009. Contrasting Eastern Pacific and Central Pacific types of ENSO. J. Clim. 22:615-632.

Lara-Lopez, A., and F. J. Neira. 2008. Synchronicity between zooplankton biomass and larval fish concentrations along a highly flushed Tasmanian estuary: Assessment using net and acoustic methods. J. Plankton Res. 30 (9): 1061-1073.

Lehodey, P., M. Bertignac, J. Hampton, A. Lewis, and J. Picaut. 1997. El Nino South Oscillation and tuna in the western Pacific. Nature 389:715-718.

Levin, L. A. 2003. Oxygen Minimum Zone benthos: Adaptation and community response to hypoxia. Oceanogr. Mar. Biol. Annu. Rev. 41:1-45.

Lowe, T. E., R. W. Brill, and K. L. Cousins. 2000. Blood oxygen-binding characteristics of bigeye tuna (Thunnus obesus), a high-energy-demand teleost that is tolerant of low ambient oxygen. Mar. Biol. 136:1087-1098.

Lu, H. J., K. T. Lee, H. L. Lin, and C. H. Liao. 2001. Spatio-temporal distribution of yellowfin tuna Thunnus albacares and bigeye tuna Thunnus obesus in the Tropical $\mathrm{Pa}$ cific Ocean in relation to large-scale temperature fluctuation during ENSO episodes. Fish. Sci. 67:1046-1052.

Ogura, M. 2003. Swimming behavior of skipjack, Katsuwonus pelamis, observed by the Data Storage Tag at the Northwestern $\mathrm{Pa}$ cific, off northern Japan, in summer of 2001 and 2002. 16th Meeting of the Standing Committee on Tuna and Billfish, 9-16 July, Mooloolaba, Australia.
Potier, M., F. Marsac, Y. Cherel, V. Lucas, R. Sabatié, O. Maury, and F. Ménard. 2007. Forage fauna in the diet of three large pelagic fishes (lancetfish, swordfish, and yellowfin tuna) in the western equatorial Indian Ocean. Fish. Res. 83:60-72.

Prince, E. D., and C. P. Goodyear. 2006. Hypoxia-based habitat compression of tropical pelagic fishes. Fish. Oceanogr. 15 (6): 451464.

Schaefer, K. M., and D. W. Fuller. 2007. Vertical movement patterns of skipjack tuna (Katsuwonus pelamis) in the eastern equatorial Pacific Ocean, as revealed with archival tags. Fish. Bull. 105:379-389.

Schaefer, K. M., D. W. Fuller, and B. A. Block. 2009. Vertical movements and habitat utilization of skipjack tuna (Katsuwonus pelamis), yellowfin (Thunnus albacares), and bigeye (Thunnus obesus) tunas in the equatorial eastern Pacific Ocean, as ascertained through archival tag data. Pages 121-144 in J. L. Nielsen, H. Arrizabalaga, N. Fragoso, A. Hobday, M. Lutcabage, and J. Sibert, eds. Reviews: Methods and technologies in fish biology and fisheries. Vol. 9: Tagging and tracking of marine animals with electronic devices. Springer, Berlin.

Scholz, F., C. Hensen, A. Noffke, A. Rohde, V. Liebetrau, and K. Wallmann. 2011. Early diagenesis of redox-sensitive trace metals in the Peru upwelling area-response to ENSO-related oxygen fluctuations in the water column. Geochim. Cosmochim. Acta 75:7257-7276.

Song, L. M., Y. Zhang, L. X. Xu, W. X. Jiang, and J. Q. Wang. 2008. Environmental preferences of longlining for yellowfin tuna (Thunnus albacares) in the tropical high seas of the Indian Ocean. Fish. Oceanogr. 17 (4): 239-253.

Stramma, L., G. C. Johnson, J. Sprintall, and V. Mohrholz. 2008. Expanding oxygenminimum zones in the tropical oceans. Science 320:655-658.

Stramma, L., S. Schmidtko, L. A. Levin, and G. C. Johnson. 2010. Ocean oxygen minima expansions and their biological impacts. Deep-Sea Res. I 57:587-595.

Swimmer, Y., L. McNaughton, C. Moyes, and R. Brill. 2004. Metabolic biochemistry of 
cardiac muscle in three tuna species (bigeye, Thunnus obesus; yellowfin, T. albacares; and skipjack, Katsuwonus pelamis) with divergent ambient temperature and oxygen tolerances. Fish Physiol. Biochem. 30:27-35.

Trenberth, K. E., and L. Smith. 2006. The vertical structure of temperature in the Tropics: Different flavors of El Niño. J. Clim. 19:4956-4970.

Wegner, N. C., C. A. Sepulveda, K. B. Bull, and J. B. Graham. 2010. Gill morphometrics in relation to gas transfer and ram ventilation in high-energy demand Teleosts: Scombrids and Billfishes. J. Morphol. 271:36-49.
Williams, A. J., V. Allain, S. J. Nicol, K. J. Evans, S. D. Hoyle, C. Dupoux, E. Vourey, and J. Dubosc. 2015. Vertical behavior and diet of albacore tuna (Thunnus alalunga) vary with latitude in the South Pacific Ocean. Deep-Sea Res II 113:154169.

Zhang, H., S. A Ludsin, D. M. Mason, A. T. Adamack, S. B. Brandt, X. Zhang, D. G. Kimmel, M. R. Roman, and W. C. Boicourt. 2009. Hypoxia-driven changes in the behavior and spatial distribution of pelagic fish and mesozooplankton in the northern Gulf of Mexico. J. Exp. Mar. Biol. Ecol. 381:S80-S91. 
